\title{
Protective effect of guabiju (Myrcianthes pungens (O. Berg) D. Legrand) and red guava (Psidium cattleyanum Sabine) against cisplatin-induced hypercholesterolemia in rats
}

\author{
Cleice Dalla Nora, Daiane Danelli, Lucéia Fátima Souza, Alessandro de Oliveira Rios, \\ Erna Vogt de Jong, Simone Hickmann Flôres*
}

Institute of Food Science and Technology, Federal University of Rio Grande do Sul, Porto Alegre, RS, Brazil

\begin{abstract}
The present study was the first to examine the protective effect and antioxidant potential of two fruits native to the south of Brazil, namely guabiju (Myrcianthes pungens (O. Berg) D. Legrand) and red guava (Psidium cattleyanum Sabine), with respect to reducing the effects of cisplatin-induced hypercholesterolemia in male Wistar rats. The cisplatin-treated animals showed high glucose, LDL cholesterol, oxidized LDL cholesterol and total cholesterol levels. These native fruits reversed the increase in these parameters. The fat levels in the liver improved with supplementation with the fruits, and there were no differences in the thiobarbituric acid reactive substances (TBARS), creatinine, urea or HDL cholesterol levels, nor in the weight of the organs analyzed, indicating that the dose used did not affect these markers.
\end{abstract}

Uniterms: Guabiju/protective effect. Red guava/protective effect. Myrcianthes pungens (O. Berg) D. Legrand/protective effect. Psidium cattleyanum Sabine/protective effect. Hypercholesterolemia/ experimental study. Cisplatin.

\begin{abstract}
O presente estudo foi o primeiro realizado para avaliar o efeito protetor e o potencial antioxidante de duas frutas nativas do sul do Brasil, conhecidas como Guabiju (Myrcianthes pungens (O. Berg) D. Legrand) e araçá vermelho (Psidium cattleyanum Sabine), em relação a reduzir os efeitos da hipercolesterolemia induzida pela cisplatina em ratos Wistar machos. Os animais tratados com a cisplatina apresentaram elevada taxa de glicose, altos níveis de colesterol LDL, colesterol LDL oxidado e colesterol total. Os frutos nativos atuaram protegendo os animais pela redução destes parâmetros. Os níveis de gordura no fígado melhoraram com a suplementação pelos frutos e não houve diferenças nas substâncias reativas ao ácido tiobarbitúrico (TBARS) e níveis de creatina, uréia e colesterol HDL e, também, no peso dos órgãos analisados, indicando que a dose utilizada não foi capaz de afetar tais marcadores.
\end{abstract}

Unitermos: Guabiju/efeito protetor. Araçá vermelho/efeito protetor. Myrcianthes pungens (O. Berg) D. Legrand/efeito protetor. Psidium cattleyanum Sabine/efeito protetor. Hipercolesterolemia/estudo experimental. Cisplatina.

\section{INTRODUCTION}

Studies have proven that the consumption of fruits is related to a low incidence of chronic degenerative diseases (Ruxton, Gardner, Walker, 2006; Van't Veer et al., 2000). Also, the benefits of native and exotic fruits have been reported in various studies. There is no doubt that fruits in

\footnotetext{
*Correspondence: S. H. Flores. Instituto de Ciência e Tecnologia de Alimentos, Universidade Federal do Rio Grande do Sul. Avenida Bento Gonçalves, 9500, Prédio 43212 - Campus do Vale, CP 15090, 91501-970 - Porto Alegre - RS, Brasil. E-mail: simone.flores@ufrgs.br
}

the diet provide compounds capable of inhibiting various diseases and of contributing to a balanced diet (Iwasawa et al., 2010).

Red guava (Psidium cattleyanum Sabine) and guabiju (Myrcianthes pungens (O. Berg) D. Legrand) are two fruits of the Myrtaceae family, and both are native to the state of Rio Grande do Sul, Brazil. Red guava is a spherical fruit, crowned by persistent sepals and red when ripe, and it has many small seeds surrounded by soft, whitish succulent pulp. It has a very pleasant sweetacid flavor. Guabiju is a spherical, velvety fruit that is 
purplish when ripe, with a succulent, yellowish pulp. It has a pleasant sweet taste and generally a single stone in the center.

Cisplatin (cis-diamminedichloroplatinum II) stands out amongst the anti-tumor agents because of its potent activity. However, this anti-tumor agent shows serious side effects against non-tumor cells, and it is capable of generating reactive oxygen species (Atessahin et al., 2005) and increasing lipid peroxidation products (Masuda, Takaka, Takahama, 1994). Chemotherapy with cisplatin induces a decline in plasma antioxidant levels, which could lead to a failure in antioxidant defense mechanisms against the damage caused by free radicals produced by anti-tumor drugs (Weijl et al., 1998). Many tropical and subtropical fruits are well known and the scientific basis for their consumption is well founded (Dube et al., 2004; Leontowicz et al., 2007). However, some others such as red guava and guabiju are practically unknown and have been investigated only in vitro (Andrade et al., 2011; Luximon-Ramma, Bahorun, Crozier, 2003; Pino, Marbot, Vázquez, 2001). We did not find any publications on studies of guabiju and red guava in vivo. Therefore, we decided to investigate these native fruits in vivo and their possible protective effect against cisplatin-induced damage when added to the diet.

\section{MATERIAL AND METHODS}

\section{Preparation of the fruits}

The samples of guabiju came from Viamão city, Rio Grande do Sul, Brazil (3004'52" south, 51 01 '24" west, altitude $111 \mathrm{~m}$ ) and were collected in February 2011. The samples of red guava came from the city of Estrela Velha, Rio Grande do Sul, Brazil (29¹0’36" south, 5309'33” west, altitude $394 \mathrm{~m}$ ) and were collected in March of the same year. The fruits were deposited in the Institute of Natural Sciences (ICN) Herbaruim of the Federal University of Rio Grande do Sul (UFRGS), under the number of the collector C. Dalla Nora 172539 and 172540 for guabiju and for red guava, respectively. The fruits were selected according to their uniformity of maturation and lack of damage and immediately frozen $\left(-10^{\circ} \mathrm{C}\right)$. The fruits were subsequently placed in a deep freezer $\left(-80^{\circ} \mathrm{C}\right)$ for $24 \mathrm{~h}$ and then in the freeze dryer $\left(-54^{\circ} \mathrm{C}\right)$ for three days. After removing from the freeze dryer, they were immediately vacuum packed in polyethylene bags and frozen $\left(-10^{\circ} \mathrm{C}\right)$ until analyzed or given to animals, when they were ground to a fine powder in a microprocessor. To prepare the red guava powder, the whole fruit was used, while for the guabiju powder, the pulp and peel was used after removing the seed.

\section{Determination of the physicochemical composition}

The following determinations were made, in triplicate, on the freeze-dried samples: moisture content (gravimetry at $105^{\circ} \mathrm{C}$ ); fixed mineral residue (muffle furnace at $550{ }^{\circ} \mathrm{C}$ ); lipid concentration (Soxhlet) and protein (Kjeldahl, with a conversion factor of 5.75), all according to AOAC methods (Helrich, 1990). The total and reducing sugars were determined by the Lane and Eynon method (1934), and the non-reducing sugars from the difference between the total and reducing sugars, multiplied by a conversion factor of 0.95 . The total carbohydrates were calculated by difference. Dietary fiber was determined by the enzymatic-gravimetric method using a Sigma-Aldrich kit.

Total titratable acidity (TTA) was determined by titration, measuring $\mathrm{pH}$ directly using a $\mathrm{pH}$ meter, and total soluble solids (TSS) by refractometry, according to AOAC methods (2007).

All the results were expressed with respect to $100 \mathrm{~g}$ dry sample.

\section{Treatment}

The animals, weighing about $200 \mathrm{~g}$, were housed in individual cages at a room temperature of $22 \pm 2{ }^{\circ} \mathrm{C}$ with a 12-hour light/dark period and a relative humidity of 70 to $80 \%$, each, obtained from the UFRGS Animal Center. All the animals had free access to water and commercial feed throughout the experiment. The treatment was carried out in the animal facility of the Department of Food Science of the Institute of Food Science and Technology (ICTA - UFRGS), Brazil, and was approved by the Ethics and Animal Welfare Committee of the same University on December 6, 2010 (protocol No. 19569).

Every day, $10 \mathrm{~g}$ of the pellets were ground, mixed with the powdered freeze-dried fruits, placed in pots and offered to the animals during the night. The amounts of fruits used, both for the red guava and guabiju, were established in a pilot test, where a daily ingestion of $300 \mathrm{~g}$ of raw fruit was determined for a $70 \mathrm{~kg}$ adult. Thus, the appropriate amount was calculated according to the body weight of the animals, and corrected for the dry weight content. The animals were weighed every other day to correct the amount of fruit offered. The average amounts of carotenoids and anthocyanins found in fruits (dry matter) was respectively $4571.3 \mu \mathrm{g} / 100 \mathrm{~g}$ and $15326.4 \mathrm{mg} / 100 \mathrm{~g}$ for guabiju and $2443.3 \mu \mathrm{g} / 100 \mathrm{~g}$ and $309.6 \mathrm{mg} / 100 \mathrm{~g}$ for red guava.

The experiment was carried out for 35 days and the animals, twenty-four male Wistar rats, were divided randomly into 4 groups, each with 6 rats, with their 
respective diets, as follows: $\mathrm{CG}$ (control group), which only received the commercial feed, $\mathrm{CPG}$ (cisplatin group), which received the commercial feed plus cisplatin; CPRG (cisplatin/red guava group), which received commercial feed plus cisplatin supplemented with red guava; and CPGG (cisplatin/guabiju group), which received commercial feed plus cisplatin supplemented with guabiju. In both treatments with cisplatin, the compound was injected intraperitoneally just 48 hours before the end of the experiment (33 days) (Silva, Antunes, Bianchi, 2001) in a single dose $(5 \mathrm{mg} / \mathrm{kg})$ (Evangelista et al., 2004). Normal saline was injected in the case of the group that only received the commercial feed (control group).

\section{Control of body weight, consumption of diet and calculation of food efficiency coefficient (FEC)}

After a two-day adaption period, the animals, divided into their respective groups, received the treatments with the fruits. The animals were weighed and the feed consumption measured every day until $48 \mathrm{~h}$ before the end of the study, at which time the adequate dose of cisplatin was given by intraperitoneal administration. The amount of diet ingested was determined from the difference in weight between that offered, the leftovers and the losses. The food efficiency coefficient (FEC) was calculated from the weight control and feed ingestion data, showing the relationship between weight gain and consumption (Pellet, Young, 1980). All indices were calculated for each animal, allowing the calculation of the means and standard deviation.

\section{Evaluation of the blood profile}

The method described by Rodrigues (2003) was used to take the blood samples, where the animals were sedated with benzodiazepine $(0.25 \mathrm{mg} / 100 \mathrm{~g}$ body weight $)$ and anesthetized with sodium pentobarbital $(4.6 \mathrm{mg} / 100 \mathrm{~g}$ body weight). Subsequently, an incision was made at the Alba line for the entire ventral part, and was blood collected from the ascending aorta and immediately centrifuged at $3000 \mathrm{~g}$ to obtain the plasma. The plasma was sent to the Pharmacy Laboratory of UFRGS, Brazil, to carry out the determinations of total cholesterol (TC), triacylglycerols (TAG), HDL cholesterol, oxidized LDL cholesterol (ox-LDL), creatinine, urea, alanine amino transferase (ALT) and aspartate amino transferase (AST). LDL cholesterol was calculated using the Friedewald equation (1972). At the moment the blood sample was taken, the blood glucose level was determined with the aid of a glucose measurement apparatus.

\section{Weight of the organs}

After collecting the blood, the liver, heart, spleen and right and left kidneys of each rat were removed, visually analyzed and weighed. The weights of the organs were compared to the fasting weights of the rats.

\section{Evaluation of the liver}

Lipoperoxidation of the liver fat was determined by the thiobarbituric acid reactive substances (TBARS) method, which measures the level of malondialdehyde (MDA) derived from peroxidation, according to the method described by Ohkawa et al. (1979). The liver samples were homogenized with $0.01 \mathrm{mM}$ Tris- $\mathrm{HCl}$ buffer, $\mathrm{pH} 7.0$, in the proportion of $1: 10 \mathrm{~mL}$, centrifuged at $2000 \mathrm{~g}$ for 10 minutes, and the supernatant used to determine the levels of thiobarbituric acid reactive substances. The products of the reaction were determined by spectrophotometry at $532 \mathrm{~nm}$. MDA was quantified using a calibration curve constructed with known concentrations and the results were expressed as nmol MDA/g sample.

To determine the fat, the liver was ground and the fat extracted using the Bligh and Dyer method (1959). The results were expressed as $\mathrm{g} / 100 \mathrm{~g}$ sample.

\section{Statistical analysis}

The data were submitted to analysis of variance (ANOVA) to detect significant differences between the groups, and Tukey's test applied when there was a difference between the means.

\section{RESULTS AND DISCUSSION}

\section{Physicochemical composition}

Table I shows the results obtained for the physicochemical composition of freeze-dried red guava and guabiju. After freeze-drying the remaining moisture content of the red guava $(30.7 \%)$ was twice that of the guabiju (13.3\%).

The residual fixed mineral content of guabiju was approximately twice that of red guava, showing a statistical difference. Fruits, especially non-domesticated ones, are rich in minerals (Kinupp, Barros, 2008), and some studies have indicated selenium and zinc as being the antioxidant minerals involved in cell defense mechanisms against free radicals (Alfieri, Leung, Grace, 1998). In a comparative study of the minerals of different native species, the following were found for red guava, in decreasing order: 
TABLE I - Physicochemical composition of freeze-dried red guava and guabiju

\begin{tabular}{lcc}
\hline & \multicolumn{2}{c}{ Fruits } \\
\cline { 2 - 3 } & Red guava & Guabiju \\
\hline Moisture & $30.66 \pm 0.06^{\mathrm{a}}$ & $13.33 \pm 0.02^{\mathrm{b}}$ \\
Ash & $1.54 \pm 0.02^{\mathrm{b}}$ & $2.81 \pm 0.02^{\mathrm{a}}$ \\
Protein & $3.25 \pm 0.02^{\mathrm{b}}$ & $8.41 \pm 0.07^{\mathrm{a}}$ \\
Lipid & $0.71 \pm 0.01^{\mathrm{b}}$ & $0.82 \pm 0.01^{\mathrm{a}}$ \\
Carbohydrate & 39.19 & 55.58 \\
Non-reducing sugar & $10.56 \pm 0.22^{\mathrm{b}}$ & $15.11 \pm 0.23^{\mathrm{a}}$ \\
Reducing sugar & $21.72 \pm 0.01^{\mathrm{b}}$ & $31.99 \pm 0.20^{\mathrm{a}}$ \\
Dietary fiber & $55.31 \pm 0.27^{\mathrm{b}}$ & $32.38 \pm 0.16^{\mathrm{a}}$ \\
Total soluble solids (TSS) & $35 \pm 0.10^{\mathrm{b}}$ & $54 \pm 0.10^{\mathrm{a}}$ \\
pH & $3.31 \pm 0.01^{\mathrm{b}}$ & $4.71 \pm 0.04^{\mathrm{a}}$ \\
Total titratable acidity (TTA) (\% citric acid) & $3.76 \pm 0.02^{\mathrm{a}}$ & $0.54 \pm 0.04^{\mathrm{b}}$ \\
\hline
\end{tabular}

Values expressed as the mean \pm standard deviation in $\mathrm{g} / 100 \mathrm{~g}$ dry matter. Values on the same row with different letters indicate statistically significant differences between the means $(\mathrm{p} \leq 0.01), \mathrm{n}=3$

potassium, calcium, phosphorus, magnesium, sulfur, sodium, manganese, iron, zinc, boron and copper (Kinupp, Barros, 2008). A similar study is required to obtain the mineral profile of guabiju.

A protein content of $3.3 \%$ was found for red guava and $8.4 \%$ for guabiju, and thus, the latter can be considered a high-protein fruit, as also other native fruits such as araçá-pitanga (Eugenia multicostata) and pessegueiro-domato (Eugenia myrcianthes), which have protein contents of 10.9 and $8.1 \%$, respectively (Kinupp, Barros, 2008).

Some amino acids have already been tested for their inhibition of the cisplatin cytotoxicity by Kroning et al. (2000), and were shown to be efficient in binding to cisplatin.

Fruits are not generally sources of lipids, and the values found for both fruits in the present study were below $1 \%$. But the lipid fraction can be composed of unsaturated fatty acids, carotenoids and liposoluble vitamins, such as vitamins $A$ and $E$, and these compounds have been shown to possess antioxidant characteristics (Stavric, 1994; Pool-Zobel et al., 1997).

Fruits are good carbohydrate sources, and the total carbohydrate content found was about $40 \%$ for red guava and $55 \%$ for guabiju. After freeze-drying, the reducing sugar content of both fruits was greater than the non-reducing sugar content. In addition to significantly higher sugar and soluble solids contents, guabiju showed significantly lower acidity than did red guava, characterizing it as a sweeter fruit.

The dietary fiber content of red guava $(55.31 \pm 0.27)$ was 1.7 times higher than that of guabiju $(32.38 \pm 0.16)$.
Dietary fiber is associated with a reduction in the occurrence of certain diseases and disorders, such as chronic intestinal disorders, obesity, type 2 diabetes, cardiovascular disease and cancer (Kris-Etherton et al., 2002). In addition, the fruits exhibit a better ratio between soluble and insoluble fiber, which is important for both health and technological characteristics (Thebaudin et al., 1997; Garau et al., 2007).

\section{Control of body weight, diet consumption and the calculation of food efficiency coefficient (FEC)}

The groups that used diets supplemented with fruits (CPRG and CPGG) did not did not show a significant increase in weight (Table II), although their diets represented increased consumption of sugars, proteins and lipids. This effect was probably due to the phytochemicals present in the fruits (Kao, Hiipakka, Liao, 2000). In the present study, the animals treated with fruits showed similar weight gain and food ingestion compared to the control group, indicating that supplementation with fruits did not cause changes in FEC (Table II) and suggesting there was no toxicity due to the fruits tested.

\section{Weight of the organs}

None of the organs showed any macroscopic lesion at the moment of removal or statistical difference in weight (Table III), which is important since an increase in weight 
TABLE II - Weight gain (WG), consumption and food efficiency coefficient (FEC) for the animals that consumed native fruits or otherwise

\begin{tabular}{lccc}
\hline & WG $(\mathrm{g})$ & Consumption $(\mathrm{g})$ & FEC \\
\hline CG & $105.67 \pm 27.51^{\mathrm{a}}$ & $918.20 \pm 75.63^{\mathrm{a}}$ & $0.11 \pm 0.02^{\mathrm{a}}$ \\
CPG & $128.72 \pm 24.82^{\mathrm{a}}$ & $932.85 \pm 94.07^{\mathrm{a}}$ & $0.14 \pm 0.01^{\mathrm{a}}$ \\
CPRG & $110.85 \pm 10.38^{\mathrm{a}}$ & $914.67 \pm 73.32^{\mathrm{a}}$ & $0.12 \pm 0.01^{\mathrm{a}}$ \\
CPGG & $123.70 \pm 25.03^{\mathrm{a}}$ & $891.16 \pm 53.68^{\mathrm{a}}$ & $0.14 \pm 0.02^{\mathrm{a}}$ \\
\hline
\end{tabular}

CG - Control group; CPG - Cisplatin group; CPRG - Cisplatin/red guava group; CPGG - Cisplatin/guabiju group. Different letters in the same column indicate statistically significant differences between the treatments $(\mathrm{p}<0.05), \mathrm{n}=6$

TABLE III - Organ weights of fasted rats

\begin{tabular}{lccccc}
\hline & Liver & Heart & Spleen & Right kidney & Left kidney \\
\hline GC & $3.21 \pm 0.22^{\mathrm{a}}$ & $0.32 \pm 0.03^{\mathrm{a}}$ & $0.22 \pm 0.03^{\mathrm{a}}$ & $0.37 \pm 0.03^{\mathrm{a}}$ & $0.36 \pm 0.03^{\mathrm{a}}$ \\
CPG & $3.13 \pm 0.20^{\mathrm{a}}$ & $0.29 \pm 0.03^{\mathrm{a}}$ & $0.21 \pm 0.02^{\mathrm{a}}$ & $0.36 \pm 0.04^{\mathrm{a}}$ & $0.36 \pm 0.04^{\mathrm{a}}$ \\
CPRG & $3.26 \pm 0.50^{\mathrm{a}}$ & $0.33 \pm 0.04^{\mathrm{a}}$ & $0.19 \pm 0.03^{\mathrm{a}}$ & $0.38 \pm 0.05^{\mathrm{a}}$ & $0.40 \pm 0.07^{\mathrm{a}}$ \\
CPGG & $3.19 \pm 0.36^{\mathrm{a}}$ & $0.31 \pm 0.03^{\mathrm{a}}$ & $0.20 \pm 0.03^{\mathrm{a}}$ & $0.38 \pm 0.04^{\mathrm{a}}$ & $0.36 \pm 0.01^{\mathrm{a}}$ \\
\hline
\end{tabular}

CG - Control group; CPG - Cisplatin group; CPRG - Cisplatin/red guava group; CPGG - Cisplatin/guabiju group. Different letters in the same column indicate statistically significant differences between the treatments $(\mathrm{p}<0.05), \mathrm{n}=6$.

could represent damage or lesion to the organ. Although the dose of cisplatin used in this study is that often used in animals (Evangelista et al., 2004), it was four times higher than what is commonly administered to humans (Jacobs et al., 1980).

Favareto et al. (2011) showed in rats given a dose of $1 \mathrm{mg} / \mathrm{kg}$ cisplatin five days a week for 3 weeks, significant differences in the weights of the kidneys and liver of the test group as compared to the control group, which could be explained by the higher doses used.

\section{Evaluation of the blood profile}

Table IV shows the values obtained for total cholesterol and HDL, LDL and oxidized LDL cholesterol for the animals that consumed native fruits or otherwise.
The values for TC were significantly higher in the CPG group than in the other groups, indicating that the native fruits acted in reducing the effects of cisplatin. The increase in TC in the CPG group was related principally to an elevation in LDL cholesterol levels, since HDL cholesterol showed no alterations due to the supplementation with native fruits or the administration of cisplatin. Thus, with respect to LDL, the native fruits acted in reducing the effects of cisplatin. The lowest values for ox-LDL were found in the CPGG group, and in the same way as for TC and LDL, the values did not significantly differ from those in groups CPRG and CG.

With respect to TAG, CG showed the highest values, differing significantly from the groups $\mathrm{CPG}, \mathrm{CPRG}$ and CPGG. Although group CPRG displayed low values, which did not significantly differ from that in groups $\mathrm{CPG}$

TABLE IV - Blood lipid profile of the animals that consumed native fruits or otherwise: Total cholesterol (TC), triacylglycerols (TAG), and HDL, LDL and oxidized LDL cholesterol

\begin{tabular}{lccccc}
\hline & TC $(\mathrm{mg} / \mathrm{dL})$ & TAG $(\mathrm{mg} / \mathrm{dL})$ & HDL $(\mathrm{mg} / \mathrm{dL})$ & LDL $(\mathrm{mg} / \mathrm{dL})$ & Ox-LDL $(\mathrm{g} / \mathrm{L})$ \\
\hline CG & $55.75 \pm 6.18^{\mathrm{b}}$ & $66.00 \pm 12.57^{\mathrm{a}}$ & $24.00 \pm 1.41^{\mathrm{a}}$ & $18.55 \pm 4.32^{\mathrm{b}}$ & $58.91 \pm 6.92^{\mathrm{b}}$ \\
$\mathrm{CPG}$ & $73.50 \pm 6.14^{\mathrm{a}}$ & $43.25 \pm 9.03^{\mathrm{b}}$ & $24.00 \pm 2.16^{\mathrm{a}}$ & $40.85 \pm 7.45^{\mathrm{a}}$ & $70.44 \pm 8.69^{\mathrm{a}}$ \\
CPRG & $58.75 \pm 6.75^{\mathrm{b}}$ & $48.50 \pm 6.61^{\mathrm{ab}}$ & $24.50 \pm 1.73^{\mathrm{a}}$ & $24.55 \pm 6.43^{\mathrm{b}}$ & $59.63 \pm 6.07^{\mathrm{ab}}$ \\
CPGG & $50.75 \pm 4.99^{\mathrm{b}}$ & $43.25 \pm 4.65^{\mathrm{b}}$ & $23.50 \pm 0.58^{\mathrm{a}}$ & $18.60 \pm 5.98^{\mathrm{b}}$ & $54.71 \pm 7.29^{\mathrm{b}}$ \\
\hline
\end{tabular}

CG - Control group; CPG - Cisplatin group; CPRG - Cisplatin/red guava group; CPGG - Cisplatin/guabiju group. Different letters in the same column indicate statistically significant differences between the treatments $(p<0.05), n=6$. 
TABLE V - Profile of the enzymes aspartate amino transferase and alanine amino transferase and creatinine, urea and glucose in the blood of animals that consumed the native fruits or otherwise

\begin{tabular}{lccccc}
\hline & AST $(\mathrm{U} / \mathrm{L})$ & ALT $(\mathrm{U} / \mathrm{L})$ & Creatinine $(\mathrm{mg} / \mathrm{dL})$ & Urea $(\mathrm{mg} / \mathrm{dL})$ & Glucose $(\mathrm{mg} / \mathrm{dL})$ \\
\hline CG & $85.25 \pm 11.56^{\mathrm{b}}$ & $40.00 \pm 5.23^{\mathrm{ab}}$ & $0.47 \pm 0.04^{\mathrm{a}}$ & $40.00 \pm 2.16^{\mathrm{a}}$ & $137.50 \pm 25.32^{\mathrm{c}}$ \\
CPG & $83.50 \pm 10.02^{\mathrm{b}}$ & $33.75 \pm 2.36^{\mathrm{b}}$ & $0.41 \pm 0.05^{\mathrm{a}}$ & $38.25 \pm 2.50^{\mathrm{a}}$ & $241.75 \pm 47.53^{\mathrm{ab}}$ \\
CPRG & $108.25 \pm 10.56^{\mathrm{a}}$ & $43.50 \pm 7.72^{\mathrm{a}}$ & $0.52 \pm 0.09^{\mathrm{a}}$ & $38.75 \pm 7.63^{\mathrm{a}}$ & $178.00 \pm 14.5^{\mathrm{bc}}$ \\
CPGG & $76.5 \pm 6.95^{\mathrm{b}}$ & $30.75 \pm 4.11^{\mathrm{b}}$ & $0.55 \pm 0.08^{\mathrm{a}}$ & $42.50 \pm 4.04^{\mathrm{a}}$ & $224.00 \pm 45.59^{\mathrm{ab}}$ \\
\hline
\end{tabular}

CG - Control group; CPG - Cisplatin group; CPRG - Cisplatin/red guava group; CPGG - Cisplatin/guabiju group. Different letters in the same column indicate statistically significant differences between the treatments $(\mathrm{p}<0.05), \mathrm{n}=6$.

and CPGG, it also failed to differ significantly from the CG group.

Leontowicz et al. (2007) studied the snake fruit and mangoisteen, two exotic fruits, for their effect on cholesterol administration. In this study, the fruits reduced TC and LDL levels, but HDL levels remained unaltered by either supplementation with the fruits or by the administration of cholesterol. These data corroborate those of the present study. Still, the fruits lowered the TAG levels. However, in that study, the TAG values increased when cholesterol was administered, in contrast to the present study, where the administration of cisplatin did not raise the level of these substances.

Table V shows the results obtained for the liver enzyme, creatinine, urea and glucose levels of animals given freeze-dried red guava and guabiju. The CPRG group, with, supplemented with red guava, showed increased ALT levels, as compared to the CPG and CPGG groups, although the latter did not differ from CG. CPRG also had increased AST levels as compared to all other groups. ALT is present mostly in hepatocytes (liver cells). When there is cellular injury, ALT reaches the bloodstream, and its serum levels may thus be measured to assess liver damage. On the other hand, AST is elevated in acute liver injury but is also present in red blood cells and skeletal and cardiac muscle, and since it is not a liver-specific enzyme, its increase can be found in the case of non-liver injury (Boone et al., 2005). In the case of hepatic necrosis, the levels of the two enzymes are equally increased (Fernandes, Almeida, 2002), which did not occur in the present study.

Yousef et al., (2009) evaluated the effect of a grape seed extract on the effects of cisplatin in rats. When the extract was administered together with the drug, it was capable of minimizing the damage, blocking the increase in plasma ALT and AST levels. However, the drug dose these authors used was higher $(7.5 \mathrm{mg} / \mathrm{kg})$, accounting for the liver damage, which did not occur in the present study.

There were no alterations in blood urea and creatinine, indicating that cisplatin did not cause kidney damage. In the above cited study by Yousef et al. (2009) the higher dose of cisplatin also caused increased levels of both urea and creatinine. When the grape seed extract was administered together with cisplatin, both these levels decreased indicating protection, such that the group that received the extract showed no significant differences compared with the control group.

Cisplatin caused an increase in blood glucose levels, which could be explained by the induced oxidative stress being associated with alterations in glucose concentrations (Rodrigues et al., 2003). The fruits acted by reducing the glucose levels, but red guava was more effective than guabiju and showed no differences with CG. Possibly components in red guava affected glycemia, allied to the fact that guabiju had a higher sugar concentration (Table I). The difference in composition and bioactivity between red guava and guabiju could have influenced glycemia.

\section{Evaluation of the liver}

The fruits acted by decreasing fat deposition in the liver (Table VI), indicating an improvement in the lipid profile, although the CPGG group did not differ from the CPG group. It appears that in the present study,

TABLE VI - Evaluation of the liver with respect to the amounts of fat $(\mathrm{g} / 100 \mathrm{~g}$ ) and TBARS (nmol MDA/g sample), for the animals that consumed the native fruits or otherwise

\begin{tabular}{lcc}
\hline & Fat & TBARS \\
\hline CG & $5.19 \pm 0.14^{\mathrm{a}}$ & $146.04 \pm 5.40^{\mathrm{a}}$ \\
CPG & $5.01 \pm 0.22^{\mathrm{ab}}$ & $138.58 \pm 12.70^{\mathrm{a}}$ \\
CPRG & $4.34 \pm 0.21^{\mathrm{c}}$ & $135.34 \pm 16.13^{\mathrm{a}}$ \\
CPGG & $4.56 \pm 0.24^{\mathrm{bc}}$ & $134.30 \pm 13.65^{\mathrm{a}}$ \\
\hline
\end{tabular}

CG - Control group; CPG - Cisplatin group; CPRG - Cisplatin/ red guava group; CPGG - Cisplatin/guabiju group. Different letters in the same column indicate statistically significant differences between the treatments $(\mathrm{p}<0.05), \mathrm{n}=6$. 
consumption of the fruits reduced the amount of fat in the liver, concomitantly reducing oxidative stress, thus showing a protective effect.

The consumption of a diet rich in fruits and vegetables could be capable of reducing fat levels (El-Beshbishy et al., 2006). Fiber is one of the main components in our diet involved in the prevention of chronic diseases, influencing the regulation not only of glycemic levels but also lipid levels (Chau, Huang, Lin, 2004). This effect may also be due to increased intake of carotenoids in a diet supplemented with fruits, since an increased consumption of these compounds has been shown to afford liver protection (Shamberlain et al., 2009).

TBARS reflect the amount of MDA formed. Its measurement is used to evaluate the extent of lipid peroxidation by free radicals, as indicator of oxidative stress (Karthikeyan, Sarala Bai, Niranjali Devaraj, 2007).

The cisplatin dose used in the present study was not capable of altering the lipids (Table VI). Moreira et al. (2005) found that a high-energy diet increased MDA levels and that supplementation with tomato powder was capable of significantly decreasing these levels.

\section{CONCLUSIONS}

This is the first study of guabiju and red guava fruits in vivo and we recommend inclusion of these fruits in disease-preventing diets. In this study, we sought to determine whether in addition to good taste, guabiju and red guava are beneficial in such diets. These fruits showed a protective effect in animals with respect to the oxidative stress caused by cisplatin. The levels of TC, LDL and ox-LDL in plasma and fat in the liver decreased with consumption of the native fruits, and the supplementation of the diet was well accepted by the animals and did not cause an increase in body weight.

\section{ACKNOWLEDGEMENTS}

This work was supported by grants from CAPES (Coordenação de Aperfeiçoamento de Pessoal de Nível Superior). Dr. A. Leyva (USA) helped with English editing of the manuscript.

\section{REFERENCES}

ALFIERI, M.A.; LEUNG, F.Y.; GRACE, D.M. Selenium and zinc levels in surgical patients receiving total parenteral nutrition. Biol. Trace Elem. Res., v.61, n.1, p.33-39, 1998.
ANDRADE, J.M.M.; ABOY, A.L.; APEL, M.A.; RASEIRA, M.C.B.; PEREIRA, J.F.M.; HENRIQUES, A.T. Phenolic composition in different genotypes of guabiju fruits (Myrcianthes pungens) and their potential as antioxidant and antichemotactic agents. J. Food Chem., v.76, n.8, p.1181-1187, 2011.

ATESSAHIN, A.; YILMAZ, S.; KARAHAN, I.; CERIBASI, A.O.; KARAOGLU, A. Effects of lycopene against cisplatin-induced nephrotoxicity and oxidative stress in rats. Toxicology, v.212, n.2-3, p.116-123, 2005.

BLIGH, E.G.; DYER, W.J. A rapid method of total lipid extraction and purification, Can. J. Biochem. Physiol., v.37, n.8, p.911-917, 1959.

BOONE, L.; MEYER, D.; CUSICK, P.; ENNULAT, D.; PROVENCHER BOLLIGER, A.; EVERDS, N.; MEADOR, V.; ELLIOTT, G.; HONOR, D.; BOUNOUS, D.; JORDAN, H. Selection and interpretation of clinical pathology indicators of hepatic injury in preclinical studies. Vet. Clin. Pathol., v.34, n.3, p.182-187, 2005.

CHAU, C.F.; HUANG, Y.L.; LIN, C.Y. Investigation of the cholesterol-lowering action of insoluble fibre derived from the peel of Citrus sinensis L. cv. Liucheng. Food Chem., v.87, n.3, p. 361-366, 2004.

DUBE, M.; ZUNKER, K.; NEIDHART, S.; CARLE, R.; STEINHART, H.; PASCHKE, A. Effect of technological processing on the allergenicity of mangoes (Mangifera indica L.). J. Agric. Food Chem., v.52, n.12, p.3938-3945, 2004.

EL-BESHBISHY, H.A.; SINGAB, A.N.B.; SINKKONEN, J.; PHAJA, K. Hypolipidemic and antioxidant effects of Morus alba L. (Egyptian mulberry) root bark fractions supplementation in cholesterol-fed rats. Life Sci., v.78, n.23, p.2724-33, 2006.

EVANGELISTA, C.M.W.; ANTUNES, L.M.G.; FRANCESCATO, H.D.C.; BIANCHI, M.L.P. Effects of olive, extra virgin olive and canola oils on cisplatin-induced clastogenesis in Wistar rats. Food Chem. Toxicol., v.42, n.8, p.1291-1297, 2004.

FAVARETO, A.P.A.; FERNANDEZ, C.D.B.; DA SILVA, D.A.F.; ANSELMO-FRANCI, J.A.; KEMPINAS, W.D.G. Persistent impairment of testicular histology and sperm motility in adult rats treated with cisplatin at peri-puberty. Basic Clin. Pharmacol. Toxicol., v.109, n.2, p.85-96, 2011. 
FERNANDES, A.C.S.; ALMEIDA, C.A. Norbixin ingestion did not induce any detectable DNA breakage in liver and kidney but caused a considerable impairment in plasma glucose levels of rats and mice. J. Nutr. Biochem., v.13, n.7, p.411-420, 2002.

FRIEDEWALD, W.T.; LEVY, R.I.; FREDRICKSON, D.S. Estimation of the concentration of low-density lipoprotein cholesterol in plasma, without use of the preparative ultracentrifuge. Clin. Chem., v.18, n.6, p.499-502, 1972.

GARAU, M.C.; SIMAL, S.; ROSELLÓ, C.; FEMENIA, A. Effect of air-drying temperature on physico-chemical properties of dietary fibre and antioxidant capacity of orange (Citrus aurantium v. Canoneta) by-products. Food Chem., v.104, n.3, p.1014-1024, 2007.

HELRICH, K. Official methods of analysis of AOAC international. 15ed. Gaithersburg: AOAC International,

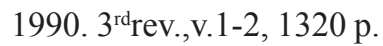

IWASAWA, H.; MORITA, E.; UEDA, H.; YAMAZAKIM, M. Influence of kiwi fruit on immunity and its anti-oxidant effects in mice. Food Sci. Technol. Res., v.16, n.2, p.135$142,2010$.

JACOBS, E.; THIERENS, H.; DE FRENNE, D.; DE CLERCQ, A.; D'HONDT, P.; DE GELDER, P.; DERUYTTER, A.J. Product yields for the photofission of $U$ with 12-, 15-, 20-, 30-, and 70-MeV bremsstrahlung. Phys. Rev., v.21, n.2, p.237-245, 1980.

KARTHIKEYAN, K.; SARALA BAI, B.R.; NIRANJALI DEVARAJ. S. Cardioprotective effect of grape seed proanthocyanidins on isoproterenol-induced myocardial injury in rats. Int. J. Cardiol., v.115, n.3, p.326-333, 2007.

KAO, Y.; HIIPAKKA, R.A.; LIAO, S. Modulation of obesity by a green tea catechin. Am. J. Clin. Nutr., v.72, n.5, p.232$233,2000$.

KINUPP, V.F.; BARROS, I.B.I. Teores de proteína e minerais de espécies nativas, potenciais hortaliças e frutas. Ciênc. Tecnol. Aliment., v.28, n.4, p.846-857, 2008.

KRIS-ETHERTON, P.M.; HECKER, K.D.; BONANOME, A.; COVAL, S.M.; BINKOSKI, A.E.; HILPERT, K.F.; GRIEL, A.E.; ETHERTON, T.D. Bioactive compounds in foods: their role in the prevention of cardiovascular disease and cancer. Am. J. Med., v.113, suppl.9B, p.71-88, 2002.
KRONING, R.; LICHTENSTEIN, A.K.; NAGAMI, G.T. Sulfurcontaining amino acids decrease cisplatin cytotoxicity and uptake in renal tubule epithelial cell lines. Cancer Chemother. Pharmacol., v.45, n.1, p.43-49, 2000.

LANE, J.H.; EYNON, L. Determination of reducing sugars by Fehling's solution with methylene blue indicator. London: Normam Rodge, 1934. 8 p.

LEONTOWICZ, M.; LEONTOWICZ, H.; DRZEWIECKI, J.; JASTRZEBSKI, Z.; HARUENKIT, R.; POOVARODOM, S.; PARK, Y.; JUNG, S.; KANG, S.; TRAKHTENBERG, S.; GORINSTEIN, S. Two exotic fruits positively affect rat's plasma composition. Food Chem., v.102, n.1, p.192200, 2007.

LUXIMON-RAMMA, A.; BAHORUN, T.; CROZIER, A. Antioxidant actions and phenolic and vitamin $\mathrm{C}$ contents of common Mauritian exotic fruits. J. Sci. Food. Agric., v.83, n.5, p.496-502, 2003.

MASUDA, H.; TAKAKA, T.; TAKAHAMA, U. Cisplatin generates superoxide anion by interaction with DNA in a cell-free system. Biochem. Biophys. Res. Commun., v.203, n.2, p.1175-1180, 1994.

MOREIRA, E.A.M.; FAGUNDES, R.L.M.; FILHO, D.W.; NEVES, D.; SELL, F.; BELLISLE, F.; KUPEK, E. Effects of diet energy level and tomato powder consumption on antioxidant status in rats. Clin. Nutr., v.24, n.6, p.10381046, 2005.

OHKAWA, H.; OHISHI, H.; YAGI, K. Assay for lipid peroxide in animal tissues by thiobarbituric acid reaction. Anal. Biochem., v.95, n.2, p.351-358, 1979.

PELLET, P.L.; YOUNG, V.R. Nutritional evaluation of protein foods. Tokyo: The United Nations University, 1980. 167 p.

PINO, J.A.; MARBOT, R.; VÁZQUEZ, C. Characterization of volatiles in strawberry guava (Psidium cattleianum Sabine) fruit. J. Agric. Food Chem., v.49, n.12, p.5883-5887, 2001.

POOL-ZOBEL, B.L.; BUB, A.; MÜLLER, H.; WOLLOWSKI, I.; RECHKEMMER, G. Consumption of vegetables reduces genetic damage in humans: first results of a human intervention trial with carotenoid-rich foods. Carcinogenes, v.18, n.9, p.1847-1850, 1997. 
RODRIGUES, H.G.; DINIZ, Y.S.; FAINE, L.A.; ALMEIDA, J.A.; FERNANDES, A.A.H.; NOVELLI, E.L.B. Nutritional supplementation with natural antioxidants: effect of rutin on HDL-cholesterol concentration. Rev. Nutr., v.16, n.3, p.315-320, 2003.

RUXTON, C.; GARDNER, E.; WALKER, D. Can pure fruit and vegetable juices protect against cancer and cardiovascular disease too? A review of the evidence. Int. J. Food Sci. Nutr., v.57, n.3-4, p.249-272, 2006.

SILVA, C.R.; ANTUNES, L.M.G.; BIANCHI, M.L.P. Antioxidant action of bixin against cisplatin-induced chromosome aberrations and lipid peroxidation in rats. Pharmacol. Res., v.43, n.6, p.561-566, 2001.

SHAMBERLAIN, S.; HALL, S.; PATEL, J.; LEE, J.; MARCUS, D.; SRIDHAR, S.; ROMERO, M.; LABAZI, M.; CALDWELL, R.; BARTOLI, M. Protective effects of the carotenoid zeaxanthinin in experimental nonalcoholic steatohepatitis. Dig. Dis. Sci., v.54, n.7, p.1460-1464, 2009.

STAVRIC, B. Antimutagens and anticarcinogens in foods. Food Chem. Toxicol., v.32, n.1, p.79-90, 1994.
THEBAUDIN, J.Y.; LEFEBVRE, A.C.; HARRINGTON, M.; BOURGEOIS, C.M. Dietary fibres: nutritional and technological interest. Trends Food Sci. Tech., v.8, n.2, p.41-48, 1997.

VAN'T VEER, P.; JANSON, M.J.C.F.; KLERT, M.; KOK, F. Fruits and vegetables in the prevention of cancer and cardiovascular disease. Public. Health Nutr., v.3, n.1, p.103-107, 2000.

WEIJL, N.I.; HOPMAN, G.D.; WIPKINK-BAKKER, A.; LENTJES, E.G.; BERGER, H.M.; CLETON, F.J.; OSANTO, S. Cisplatin combination chemotherapy induces a fall in plasma antioxidants of cancer patients. Ann. Oncol., v.9, n.12, p.1331-1337, 1998.

YOUSEF, M.I.; SAAD, A.A.; EL-SHENNAWY, L.K. Protective effect of grape seed proanthocyanidin extract against oxidative stress induced by cisplatin in rats. Food Chem. Toxicol., v.47, n.6, p.1176-1183, 2009.

Received for publication on $19^{\text {th }}$ February 2013 Accepted for publication on $30^{\text {th }}$ January 2014 
